\title{
ASEAN between China and America: Is It Time to Try Horsing the Cow?
}

\section{Donald K. Emmerson}

\begin{abstract}
Admirers of ASEAN are impressed with the fact that it continues to exist and that an outright war has never broken out between its members. Also often praised is the value to the region of promoting cooperation through the consensual process known as the 'ASEAN Way'. If ASEAN is a talk shop, these observers say, talking is at least better than fighting. ASEAN's increasingly numerous and vocal critics reply that by valuing process more than product, consensus over accomplishment, the organization is failing to respond to urgent real-world challenges in Asia. Not least among such challenges is Chinese expansion in the South China Sea (SCS) and the stated intention of incoming US president Donald Trump to pull his country out of the Trans-Pacific Partnership (TPP). Only four ASEAN members have claims in the SCS and only four are in the TPP, but the sea's and the treaty's futures matter for the rest of the region as well. The fact of Chinese advancement and the risk of American disengagement are endangering the autonomy and relevance of ASEAN, not to mention the repercussions of Sino-American escalation. Already weakened by internal dissensus, the group's ability to negotiate as a group with China on maritime security has been blocked by Beijing's insistence on bilateral talks. Chinese material largesse has coopted Cambodia into vetoing any ASEAN agreement to restrain, moderate, or even question China's designs on the heartwater of Southeast Asia. The ASEAN Way is being used against ASEAN itself. Heightened uncertainty as to America's future role in and commitment to the region further heightens security concern. In its $50^{\text {th }}$ anniversary year, Southeast Asians would do well to think outside the increasingly marginalised, internally divided, and procedurally restricted box that ASEAN has become. Three ideas already in circulation illustrate the kind of creativity that ASEAN will need if it is to sustain its acknowledged historical success in fashioning an independent political and economic identity for Southeast Asia.
\end{abstract}

KEYWORDS: ASEAN, China, America, TPP, South China Sea, Singapore

$\mathrm{O}$ N 8 August 2017, the Association of Southeast Asian Nations (ASEAN) will commemorate its birth on 8 August 1967. Those two Tuesdays will bracket the first fifty years of a renowned regional arrangement. At ASEAN's birth in then-turbulent times, who could have known that it would survive to enjoy 
middle age? For sheer longevity, ASEAN deserves kudos. One can hope that it will live long and productively enough to mark its hundredth birthday in 2067.

Impending anniversaries are more than occasions for celebration, however, as the qualification 'productively' implies. They also prompt, or should prompt, explanation, evaluation, introspection, and recommendation, as in this special issue of TRaNS. It is not an exaggeration of the value of ideas-always a hazard of academics - to say that the future performance of ASEAN will depend in no small part on the willingness of its leaders, managers, followers, and observers in its semicentennial year to balance congratulation with assessment.

\section{BeING AND DoIng}

In the United States in the late 1960s and early 1970s, a graffito often encountered on the walls of men's bathrooms - I cannot vouch for the women's rooms-read as follows:

"To be is to do"-Socrates

"To do is to be"-Jean-Paul Sartre

"Do be do be do"-Frank Sinatra

By what measures should ASEAN be judged? By the sheer fact of its existence in a zone of unrest once known as the Balkans of Asia? Is it validation enough for ASEAN to have survived as an ongoing embodiment of regional peace and cooperation, especially given the limitations built into its very nature?

Or should one apply a stricter standard, looking beyond ASEAN's longevity to its performance, what it has done and not done-by its record of addressing or ignoring pressing problems faced by the now more than 620 million people of Southeast Asia and their respective states?

Scholarly ratings of ASEAN run the gamut from five stars to none-from approbation to demolition, from the appreciative views of constructivists such as Amitav Acharya and the late Estrella Solidum to the acerbic critiques by realists such as Lee Jones and David Martin Jones (unrelated). ${ }^{1}$

At the risk of emphasizing polarity at the expense of complexity and nuance, consider the following imaginary rendition of that academic debate.

\section{Being Matters}

The constructivist says:

"Being matters. Resist the American fixation on action, on deliverables, on doing. ASEAN's strength lies in the consensus-requiring 'ASEAN Way'. The

${ }^{1}$ See Acharya 2014; Lee Jones 2010; Jones and Smith 2006. Earlier writings are referenced in Emmerson 2005. 
organisation is not about deeds. It's about words and norms. ASEAN lacks hard power. It compensates for that lack by using soft power to turn words into norms. That accomplishment has driven the organisation's success, including its very survival.

"Remember, no two ASEAN members have ever fought a war. Norms of peaceful cooperation and dispute settlement have taken hold. Southeast Asia has prospered. What other grouping can match that record of success? Just look at the present and future disarray inside the European Union. The divisive throes of 'Brexit' - the EU's renunciation by all or part of the United Kingdomcould persist into 2019 or beyond. Europe's backlash against immigration could renew border controls in the visa-free Schengen Area. Greece's debt crisis could propel its economy out of the eurozone. Had the EU been less inflexibly committed to open borders, less intrusively obsessed with supranational rules - the minimum size of a banana_its predicaments would be less visceral today.

"How has ASEAN, in contrast, managed to hold together? Consider the gaps in wealth between its member states: Singapore's per capita GDP in 2015 exceeded US\$ 53,000. Comparable figures for the Philippines, Vietnam, Myanmar, Cambodia, and Laos ran downward, in that order, from less than US\$3,000 to well under $\$ 2,000$, and all of those five economies are significantly more corrupted and less disciplined than Singapore. Yet Singapore has not bid ASEAN goodbye. Why? Because ASEAN's founders and their successors wisely avoided the codified and controlling 'European Way'. They chose instead the usefully permissive, national-sovereignty-based ASEAN Way. It makes no sense to be disappointed by ASEAN's inability to do what it was never meant to do, and therefore never designed to do.

"ASEAN cannot and should not abandon the twin commitments that have driven its success: respect for the autonomy of its constituent states and non-intervention in their domestic affairs. ASEAN has endured in large measure because of what it could not and therefore did not do. What if, for example, ASEAN had tried to implement the so-called 'responsibility to protect' by intervening to shield Rohingya Muslims from Buddhist abuse and violence in Myanmar? The association would have broken apart, and with it the regional comity that it has been able so effectively to foster. Call me a constructivist if you will, but I'm being realistic.

“Self-styled realists once ridiculed ASEAN as an 'Asian NATO'- No Action, Talk Only’. But words matter, and they have effects. By talking, by emphasizing process as well as product, ASEAN has established enduring norms of cooperation that undergird the prosperous peace that Southeast Asians continue to enjoy”. 


\section{Doing Matters}

The realist replies:

"Doing matters. ASEAN has escaped intramural war, but responsibility for a negative-what did not happen — is hard to assign. Correlation is not causation. And here is just one disturbing instance of what the group has not done:

"In 2015 the endemic annual regional haze from illegal peat-burning on Sumatra again reached health-damaging levels in Singapore and Malaysia, and was felt even in Thailand. The recurrent advent of 'the haze' has been recorded for almost half a century, since 1972. Yet three decades went by before the ASEAN states finally signed an 'ASEAN Agreement on Transboundary Haze Pollution' in 2002.

"Another dozen years passed before the culprit country, Indonesia, ratified the agreement. At an ASEAN gathering of environmental ministers in August 2016, a 'road map' out of the haze was declared. But its details were vague and the Indonesian minister did not even bother to attend. Today, after five decades of practicing the ASEAN Way, Southeast Asia is more blighted by lifespan-shortening air pollution than any other region in the world (World Health Organization 2016).

"ASEAN has two dispute settlement mechanisms: the High Council established in 1976 and the Enhanced Dispute Settlement Mechanism created in 2004. Neither has ever been used. This is not because disputes between ASEAN members do not exist, but because the states involved do not trust ASEAN and its consensus-shackled, enforcement-free, lowest-common-denominator ASEAN Way enough to submit their disputes to its indecisive processes. Tensions are instead resolved bilaterally, by recourse to international courts, or they are not resolved at all.

"ASEAN acquired a legal personality through the adoption of its Charter in 2007. Naïve observers pictured a strengthened organization that would finally get urgent things done. Instead, time went by, until ASEAN passed a different milestone when the annual frequency of ASEAN-related gatherings reached and exceeded a thousand a year (Kyaw 2012).

"This is not to deny what ASEAN has accomplished in regional diplomacy and economic cooperation. ASEAN is the initial ' $A$ ' in many acronyms-ADMM, AEC, ARF, APT, ${ }^{2}$ and so on. ASEAN's unanimity rule has not always precluded progress. In May 2016, for example, Indonesia and Laos did finally join the other eight member states in ratifying a long-pending ‘open skies' agreement promoting linkages by air.

${ }^{2}$ Respectively: ASEAN Defense Ministers Meeting, ASEAN Economic Community, ASEAN Regional Forum, ASEAN Plus Three. 
"But in the South China Sea, the ASEAN Way of multilateral consensus is losing badly to the 'Chinese Way' of unilateral expansion. China has in essence bribed Cambodia into becoming its client state. Phnom Penh has been turned virtually into an extension of Beijing's foreign policy-repaying Chinese economic favours by vetoing any effort by ASEAN to criticize, let alone counter, China's appropriation of the South China Sea (SCS). By dividing ASEAN, by using the group's own veto-vulnerable unanimity rule to enforce its silence and compliance, China is pushing the organization toward impotence, irrelevance, and eventual acquiescence in the regional primacy of Xi Jinping's Beijing. Ironically, the consensual ASEAN Way that constructivists have admired for fostering solidarity has, in China’s manipulating hands, abetted division instead".

\section{Alarm Bells and Litmus Tests}

The merit of one side in a debate is not a function of its popularity. Majorities can be wrong; currency and credibility are not the same. But in recent writing on ASEAN, constructivist optimism has been displaced by realist pessimism. Norm-driven appreciations of process over product have given way to conflictcentred criticism in which the grouping's ability merely to 'be' is outweighed by its failure to 'do' much of anything about rising geopolitical insecurity in the region, especially in the SCS.

In an April 2016 piece, veteran Asia analyst Philip Bowring (2016) wrote a not-so-mock obituary for ASEAN_"(1967-2016)"-featuring “GAME OVER" etched on the image of a gravestone. In support of that epitaph, he cited China's apparent success in coopting "three minnows" — not just Cambodia but Laos and Brunei as well-to support China's stance on the SCS.

China effectively declares invalid the positions of four of its rival claimantsBrunei, Malaysia, the Philippines, and Vietnam-and by denying the sovereign independence of the fifth-Taiwan-denies Taiwan's right to make its own claim, even if that claim matches China's. Exclusive validity is reserved in Beijing for China's own 'indisputable' sovereign prerogative over nearly all of the SCS's waters and/or land features and associated resources. Beijing has also refused to abandon or clarify its ambiguously expansive 'nine-dash line' that, on Chinese maps, cuts deeply into the internationally recognised coastal Exclusive Economic Zones (EEZs) of China's littoral neighbours, bringing Chinese rights of possession or usage close to Southeast Asian shores.

ASEAN's impotence, Bowring wrote, could be "denied no longer. China has spoken: ASEAN is irrelevant". He did not explicitly question the constructivist faith in shared norms, but he could have done so by contrasting ASEAN's evident disunity with its wishful motto, "One Vision, One Identity, One Community". 
In 2016, Bowring was not the only observer to notice ASEAN's shortcomings and vulnerability to marginalization. Three Indonesian analysts warned that China's aggressive behaviour, by worsening Sino-American rivalry, "could render ASEAN increasingly irrelevant". Were Indonesia to ignore the association and the interests of its member states in withstanding the repercussions of bigpower contention, these authors argued, "ASEAN will break apart” (Suropati et al. 2016). Indonesia's ambassador to the UK wondered whether "a postASEAN regional order" might be in the making in East Asia (Sukma 2016). His concern echoed former Indonesian foreign minister Hassan Wirajuda's worry that ASEAN was "unable to cope" with the tensions over the SCS (quoted in Chan 2016). Another leading Indonesian analyst did express confidence in ASEAN (Wanandi 2016 responding to Emmerson 2016). Like Wirajuda, however, he worried that the group could lose its relevance if did not "get its act together" on the SCS (Martel 2017 quoting Wanandi).

"ASEAN is failing," a Malaysian businessman wrote. Nevertheless, "in a pattern of self-deception which has become a regional characteristic, ASEAN — and its intellectual apologists - continue to deny what is plain for all to see. ... The leaders talk grandly about a 'People-Centric [ASEAN]'. Yet they cannot even make sure there are ASEAN lanes at all ASEAN airports and points of entry. They cannot even get an ASEAN Business Travel Card issued. Yet it is the economy and the [free] movement of people to drive it that could be the saviour of a failing ASEAN" (Majid 2016).

"ASEAN-centred multilateralism has become institutionalized as bureaucratic ritual, driven by inertia”, lamented an American analyst (Manning 2016). "Ministers and heads of state meet, wear funny shirts, play golf, make declarations and go home". "If ARF [the ASEAN Regional Forum], EAS [the ASEAN-sponsored East Asia Summit] and other such acronyms disappeared tomorrow, would Asia be any less secure? The answer is: Probably not". Cambodia and Laos, "beholden" as they are to China, have effectively given "Beijing a veto over ASEAN decisions affecting China". The ASEAN Way is "a dead end". Yet "no one will point out that the emperor [ASEAN] has no clothes".

"ASEAN Adrift" (Chong 2016: 2); "Storm clouds are gathering" (Storey 2016); “ASEAN Split” (Joshi 2016); “Time to Rethink” (Miller et al. 2016); "The End of ASEAN?" (Heydarian 2016) ... The critiques continue, echoing less frequent earlier alarm, as in "ASEAN Paralysis" (Lintner 2014) and “Could ASEAN Drift Apart?” (Wade 2011).

Many of these arguments place major responsibility for ASEAN's predicament on China's divisive and expansionary moves in Southeast Asia, especially in the SCS. But the nudity of the emperor is lamented as well-ASEAN's own structural inability to jointly maximise China's cooperation while minimizing Chinese manipulation and the prospect of Chinese subordination, especially again in the SCS. Remarkably, however, so far, on these two fronts-managing China and reforming ASEAN-there is little public evidence of creative 
remedial thinking inside the relevant foreign ministries. One can hope for more creativity on these matters among policy scholars as well.

\section{Litmus-testing China}

There is no single 'Southeast Asian' view of China, or of the United States. ASEAN's member countries are not identically uneasy plots of grass, homogeneously fearful of being trampled by Chinese and American elephants-at-war. All ten lack size and power, however, compared with both the adjacent behemoth and the distant one. Shared weakness prompts a common need to be reassured by the mammoths, however differently such assuaging may be defined and sought across the region.

Compared with their counterparts elsewhere in Southeast Asia, Singapore's leaders and analysts are more boldly realist and more openly strategic in how they construe reassurance. Insofar as their candour may express what others in the region may feel but not say, it will be helpful to compare two different 'litmus tests' of the elephants' intentions - a test for China proposed by an analyst in one of Singapore's think tanks, and a test for America suggested by the city-state's prime minister, both seeking reassurance in August 2016.

Tang Siew Mun heads the ASEAN Studies Centre in Singapore's ISEASYusof Ishak Institute, having relocated from Malaysia in 2014. "The ball is in China's court to soothe ASEAN's strategic anxieties", he wrote in ASEANFocus (Tang 2016: 7). China's future behaviour in the South China Sea would be "instructive in serving as a litmus test on China's dispensation of its enormous political, economic and military power. Will ASEAN, being the weaker party in this partnership, 'suffer what they must'? Will China break the Melian Dialogue 'curse' to establish itself as an enlightened major power?”

Wisely, Tang did not try to make a $10^{\text {th }}$ century CE construction of a $5^{\text {th }}$ century BCE debate in the Mediterranean match conditions in $21^{\text {st }}$ century Southeast Asia-surely a Procrustean task. But the 'Melian Dialogue' between Athens and Melos does have referents today. Imagine that Athens is China, the island of Melos is Singapore, and the off-stage Sparta is America. With an apology to historians, and assurance to readers that fiction is not prediction, the dialogue can be fancifully recast in these present-day Southeast Asian terms:

The Athenians (Chinese) are threatening the island of Melos (Singapore). To dissuade Athens (China), the Melians (Singaporeans) argue that Sparta (the US), being a major power, will defend them. The Athenians (Chinese) reply that the Spartans (Americans) are realists who will not come to the aid of Melos (Singapore) because the island doesn't matter enough to Sparta (the US) to cause its involvement. The Melians (Singaporeans) disagree; they put their trust in the help they expect to receive from Sparta (the US). Besides, they say, attacking us would be immoral. They offer to be friends with Athens (China) and to negotiate a mutually agreeable treaty after which the Athenians (Chinese) would 'retire from our country'. 
The Athenians (Chinese) admonish the Melians (Singaporeans) for staking so much on, and trusting so much in, the Spartans (Americans), and predict: "You will be most completely deceived". As to the argument that attacking the island would be immoral, the Athenians (Chinese) give a quintessentially realist reply: "The strong do what they can and the weak suffer what they must". Whereupon they take over the island (cf. Thucydides [416 BCE]).

\section{China Fails the Test}

To project a scenario from one hemisphere to another across 2,500 years of history is obviously not to suggest, first, that a Sino-American war will occur, or second, that if it does, the People's Liberation Army will end it parading in triumph down Singapore's Orchard Road. But it does prompt thoughts about three aspects of regional security discourse in Southeast Asia that are often overlooked: default realism, false equivalence, and bespoke reassurance.

Default realism: In the ancient Aegean Sea, the Melians were hopefully moral, but Athens failed to comply. Albeit in an officially peaceful way, China under $\mathrm{Xi}$ Jinping has failed Tang's comparably ethical 'litmus test' in the South China Sea. In the latter body of water, far from being an "enlightened major power", Beijing has behaved as an angry and adamant claimant: neutering ASEAN by using bribes to block consensus; denying access to fishermen from ASEAN countries; using its own fishermen to breach the EEZs along ASEAN's coasts; weaponising land features; violating the 2002 Declaration on Conduct; and denouncing an international court's ruling against its far-flung self-assigned 'nine-dash' perimeter after having refused even to participate in the case. ${ }^{3}$ Beijing could hardly have mounted a more viscerally realist refutation of the 'ASEAN Way'.

In ASEAN-related policy discourses inside Southeast Asia, the boost that Beijing's maritime assertions have given to realist perspectives has not yet expunged the more sanguine views associated with constructivist faith in consensus and the power of norms. However, 'default' or 'fallback' realism is itself becoming a norm in more than a few Southeast Asian states: From China, hope for the best. But prepare for worse, and buy more weapons, just in case.

False equivalence: Traditionally, most ASEAN states, most of the time, have hedged in both directions_-against Beijing and Washington alike. The ostensible symmetry has fostered a false sense of equivalence between the elephants. The equivalence is false because, although it is extremely unlikely that China (cf. Athens) will ever attack and absorb Singapore (cf. Melos), it is even less plausible to think that the US (cf. Sparta) will do so. The geographical fact of China's

\footnotetext{
${ }^{3}$ The court was convened over China's objection but in keeping with the provisions of the UN Convention on the Law of the Sea (UNCLOS). Since the court's ruling, China has downplayed the 'nine-dash line', apparently preferring to express its claim in language that comes closer to the terminology used in the Convention. Of interest on this score is Chubb 2016. That said, the ferocity, ambiguity, and UNCLOS-incompatibility of China's claim remain.
} 
proximity guarantees China a permanent place on Southeast Asian policy agendas. The unilateral extension of Chinese sovereignty to the shores of Southeast Asia would enlarge, and be enabled by, that immutable nearness.

More than a century ago, a Mexican president rued his country's permanent location "so far from God, so close to the United States" (Eisenhower 2000). Mexico is not Southeast Asia; God is not an American; the US is not China. But security-minded realists in the capitals of ASEAN, including in Singapore, know full well that their region is "so far from the US" and "so close to China." In the eyes of realists in Southeast Asia, the dissimilarities between the two elephants, including this difference in distance, not only falsify the notion that they are equivalent. Refuted as well is the wishful symmetry that takes comfort in equidistance, as if the safest place for a Southeast Asian to stand were exactly half-way between two giant outsiders, who are in fact neither equally ominous nor equally rewarding. To oversimplify: In present conditions, the American threat lies in its absence; China's threat stems from its presence.

Bespoke reassurance: If clothing made to order is bespoke, so are the distinctive reassurances that Southeast Asian realists would like to 'order' from China and the US. Reassurance is subjective. What assuages one ASEAN leader may not relieve another. Consider Cambodia's strongman Hun Sen. When he thwarts ASEAN on the South China Sea, the reassurance he wants from China is to be paid for his trouble. In such a calculus, Beijing's comparative advantage is financial and political. The regime in Phnom Penh welcomes Chinese funds, uses them to strengthen itself, and knows that its violations of human rights will not worry Beijing. Whether China will "soothe ASEAN's strategic anxieties" in the SCS-Tang Siew Mun's concern in Singapore-has little traction in Phnom Penh. Hun Sen's 'litmust test' for China is narrower and more direct: not to moderate its regional ambition and become an "enlightened major power", as Tang would have it, but to continue to inoculate its Cambodian client with bilateral injections of aid.

In mid-June 2016, an ASEAN statement on the SCS that would have angered Beijing was derailed with the help of Phnom Penh. On 12 July in The Hague, China's nine-dash line was, in effect, ruled invalid under international law. Three days later, China's prime minister promised Hun Sen another large grant in yuan, then worth more than half a billion dollars. At another ASEAN meeting nine days after the gift was announced, Cambodia again used ASEAN's rule of consensus to please China by preventing the association's foreign ministers from even mentioning the court's decision in The Hague. ${ }^{4}$

Xi Jinping's China failed Tang's test. ASEAN was split and silenced by Chinese bribery and intimidation. These were the acts not of an "enlightened major power" but of an intransigently selfish one. Beijing had wrecked its

${ }^{4}$ For details and context, see Parameswaran 2016a; Paviour and Naren 2016; and Mogato et al. 2016. 
neighbours" ability even to question China’s “indisputable” would-be dominance in the waters that, after all, lapped their shores as well.

\section{Litmus-testing America}

If China was litmus-tested by a strategic thinker in Singapore, it took another Singaporean voice to litmus-test the United States. In August 2016 the city-state's prime minister Lee Hsien Loong discussed the Trans-Pacific Partnership (TPP) before an audience of American officials and businesspeople in Washington, DC. That lengthy, complex, intrusive, and controversial agreement had finally been signed six months earlier by Singapore, the US, and ten other Asian-Pacific states. As Lee reminded his listeners, the dozen signers' economies covered two-fifths of global GDP, a third of world trade, and "a market of 800 million people” (Lee 2016). He did not mention China, but that last figure, meant to make the pact attractive, was telling in a different way: 1.4 billion Chinese, including $\mathrm{Xi}$ Jinping, were not on board. Nor did Lee need to say that the Chinese Communist Party might not like certain provisions of the TPP, such as those meant to prevent thefts of intellectual property, encourage independent labour organizations, foster good governance including transparency, and protect the environment from pollution in ways that could further slow China's decelerating rate of economic growth.

Lee acknowledged that even the twelve who signed on to the TPP had reservations. All of them had made "sacrifices." All wanted "something better". But none wanted to "re-open negotiations"-eight years of deliberation, he might have added - "with no prospect of doing better, and every chance of having it fall apart". And then, in urging his American audience to work for American ratification of the TPP, he explained why it was so important. "Asian countries want America to be engaged," he said. "We need to know that this engagement will be sustained [and] that Asia can depend on America. Your ratification ... will be a clear statement of your commitment to and your confidence in the region”.

Lee continued: "America has helped create and maintain the current world order and international rules that we all have a stake in and all countries benefit from. No other country has the economic capacity, political strength or the soft power to play this role. It is America's primary responsibility-unescapable-as the preeminent global power, to continue to chart the course ahead for the world". He could have added: Are you listening, China? Instead he challenged his American audience: "Ratifying TPP is a litmus test of your credibility and seriousness of purpose".

Lee did not ignore ASEAN in his speech. He mentioned various ASEANrelated regional economic arrangements, including two linked to China: the ASEAN-China Free Trade Area (ACFTA) and the still not completed Regional Comprehensive Economic Partnership (RCEP). But his real concern was not with the presence of these or other products and projections of the ASEAN Way; it was the absence of the US from all of them. 


\section{America fails the test}

When Singapore's Lee spoke in Washington, he knew that American opposition to TPP ratification was high and rising, buoyed by popular opposition to ostensibly job-killing trade agreements. In 2015, in a debate with rivals to become the Republican Party's presidential nominee, Donald Trump had called the accord "a horrible deal ... leading to nothing but trouble ... a deal that was designed for China to come in, as they always do, through the back door, and totally take advantage of everyone" (quoted in Weissmann 2016).

The self-assured ignorance of that meretricious remark was astonishing, especially coming from someone with the presumption, but not the knowledge, to become president. China was never a member of the TPP. The TPP was a front door for the US, not a "back door" for China. Beijing preferred RCEP, where it did belong and the US did not, over the TPP, which China was leery of joining. Had it tried it to do so, China would have had either to accept supposedly 'American' liberal rules or to overcome the other members' likely refusals to re-open the negotiations. In the latter event, far from conspiring to sneak China into the agreement as an anti-American Trojan horse, the TPP's Asian members would likely have wondered whether China wanted to destroy the pact by prolonging its revision, much as Beijing had done to the prospect of a code of conduct in the South China Sea by endlessly delaying that negotiation.

Events made the speculation moot. In July 2016, Trump won the Republication nomination. His opponent, Hillary Clinton, reversing her earlier support for the TPP, came out against it in October. On 8 November, despite losing the popular vote to her by more than 2.7 million ballots nationwide, Trump won the White House by prevailing in the constitutionally definitive, state-sizeadjusted electoral college. Three days later, Congressional opposition to the TPP caused lame-duck president Obama to acknowledge that American ratification had "no path forward" (Mauldin 2016).

Could American ratification still occur? Basically, as of mid-December, that chance had vanished. Prime Minister Lee had received his answer: America had failed his litmus test. It would not lead. It would leave. It would leave a vacuum in economic diplomacy for Beijing to fill, possibly through RCEP, without having the Americans around. One could picture the Chinese laughing all the way to the bank-their new Asian Infrastructure Investment Bank (AIIB) that the Obama administration had foolishly refused to join, privately campaigned against, and publicly failed to stop.

America had failed both tests, Lee's and Tang's. In Lee's Thucydidean-realist terms, by abandoning the TPP, the US (Sparta) behaved as if to abandon Asia, including Southeast Asia, including vulnerable Singapore (Melos). The Americans gave up on a project they themselves had led. In doing so they wasted not only their own contribution. They wasted as well the accumulated time and energy of their Asian co-negotiators, including Singapore. The TPP talks 
were not a Melian Dialogue; war was not involved; and the conversations differed in myriad other ways as well. Yet if one listened closely to the discourse following the American withdrawal and the TPP's apparent collapse, one might have heard an echo in Mandarin of what Athens had so presciently foretold for Melos in the Aegean 2,500 years before: "You will be most completely deceived". Nor, in the power-balancing terms of Tang's test, did the American abdication resemble what the four good-faith ASEAN-state negotiators expected of "an enlightened major power".

If there were a saving grace, it was that a division of ASEAN into members and non-members of the TPP would not occur. But in many (not all) ASEAN capitals, that ostensible unitarian advantage was outweighed either by local interest in someday joining a successful TPP, or by local worry that its disappearance would open a vacuum in economic regionalism that China was all too prepared and eager to fulfil. Without a TPP to secure an American commitment, China would be free to see if a US-less (but not useless) RCEP could be used to coopt ASEAN more fully and reliably into an economic sphere congenial to Chinese interests and unavailable to the US and its reformist ideas.

\section{The South China Sea and the TPP}

The same three aspects of regional security discourse raised by China's failure to meet the test of Tang also highlight the possible implications of America's failure to meet the test of Lee.

Default realism: Although China's behaviour in the SCS has caused increases in defence spending by some ASEAN states, they know that they cannot rival China militarily. Therein lies the importance of an American presence-to balance Chinese power in the way that local states cannot. But what does default realism recommend when the US loses interest in playing that role? In that case, in the ASEAN region, strategies may change. In the face of American indifference or reluctance, local leaders may shift from resistance to acceptance. Having compared the high cost and futility of countering China unaided with the material rewards that aligning with China could yield, a government in Southeast Asia might 'Finlandize' itself_aligning with Beijing on foreign policy while hoping to keep the reins of domestic policy in its own hands. And if the US were perceived as actually withdrawing from the region, a willingness to accommodate China could segue into bandwagoning. Japan is the one other Asian power that could, to an extent, replace a cancelled American insurance policy in Southeast Asia. But Tokyo may decline to go that far, even under its venturesome prime minister Shinzo Abe. And if the US were also to weaken its security guarantee to Japan, as intimated by Trump during his election campaign, Tokyo would likely be even less apt to play back-up against Beijing in Southeast Asia. 
When Chinese leaders solicit Southeast Asian support, they often speak of sharing with their ASEAN neighbours a "community of destiny". The phrase infers the inevitable from the unavoidable-China's primacy from its adjacency. By further implication, that destiny overrides, or at least envelops, the "communities" of ASEAN reviewed in this special issue of TRaNS. For Southeast Asians, in the absence of external (American) restraint, what could be more realistic by default than adapting to a necessary future?

As for the relative appeal of moral norms and material benefits, one Southeast Asian realist invented this cautionary tale for an American audience in San Francisco in February 2016:

Imagine the leader of an ASEAN state sitting at a table in a room. President Obama walks in with an offer: a high stack of papers full of principles. [Listening, one thought of the thousands of pages of rules in the TPP.] Obama puts the principles on the table and leaves. Then president Xi walks in. He carries and offers high stacks of cash. He puts the Chinese money on the table next to the American principles. If you were the ASEAN leader, which offer would you take?5

The lack of liberal democracy in Southeast Asia (Freedom 2016) reinforces the default-realist moral of this story. In a real-life variation, China has tabled, and Cambodia has taken, two stacks: Chinese money (Kynge et al. 2016) and Chinese principles (Amaro 2016). The latter will be taught in a five-year program of Chinese funding, training, and guidance as to how Cambodia should overhaul-'reform'-its legal system, presumably in keeping with China's own concentration-of-powers model in which the party bends the law.

False equivalence: The TPP treaty specifies that, before it can come into effect, at least half of the dozen signatory states must have ratified it, and the ratifiers' combined GDP must equal at least 85 percent of the GDP represented by all twelve. This means that if either of the two largest participating economies, Japan or the US, fails to ratify the TPP, it will die. On 10 November 2016, Japan's House of Representatives ratified the pact. But on 28 November, president-elect Trump promised that, on 'Day One' of his administration (following his inauguration on 20 January 2017), he would issue "a notification of intent to withdraw from the Trans-Pacific Trade Partnership", which he called "a potential disaster" for America (Donald Trump 2016). The TPP then became, for the interim, a zombie-not dead, not alive, but doomed.

President Obama's 'pivot' to Asia had been more about security than economy. America's armed forces were still superior in quality to China's. In that competition, Washington enjoyed a comparative military advantage that

${ }^{5}$ Paraphrased oral remarks by a speaker at a US-ASEAN Business Council conference on the ASEAN Economic Community, San Francisco, 17 February 2016. 
compensated in part for its distance. Beijing's comparative advantage, alongside proximity, was economic, especially regarding trade with, and financing for, the ASEAN states. Even though only four ASEAN members (Brunei, Malaysia, Singapore, and Vietnam) had been inside the room negotiating the TPP, its American imprimatur implied an economic commitment to the region in general. That commitment would have complemented the security side of the pivot, reducing China's comparative advantage as an economic partner in Southeast Asia. The TPP was in part a stack of principles, less fungible than a stack of cash. But the boosts to GDP expected to flow from the pact were attractive, and would have helped Southeast Asia to depend less on Chinese grants and loans usable as policy leverage by Beijing. Southeast Asian negotiators knew that a successful TPP could earn leverage for themselves against an eventual "common destiny" that Beijing might design and impose.

In the realm of security, the notion of Sino-American equivalence had been falsified by the implausibility of any American threat in the South China Sea comparable to China's irredentist behaviour there. Littoral states could strengthen military relations with Washington without fear of abetting American territorial ambition. The TPP was different. It would not have restored Sino-US equivalence in the commercial realm. China might well have remained Southeast Asia's main trading partner. But the TPP's collapse and the damage to American credibility and commitment could only falsify Sino-American equivalence to the detriment of Asian economic choice. The elephants were shown to be unalike in a way that favoured China. The Americans had defected from an arrangement largely of their own inspiration, abandoning unratified the very principles they had so laboriously negotiated. What was left on the table? Stacks of Chinese cash.

Bespoke reassurance: The failures of China and the US to pass their respective Singaporean litmus tests has stoked uncertainty in Southeast Asia. Reassurance is no longer bespoke; it is hard to know what to order from whom. Should Southeast Asians henceforth rely on China for economy and security alike? Or should reassurance be specialised through a division of labour whereby China is placated by economic interdependence, while the US discreetly counterbalances China in the security domain. Will Beijing or Washington agree to such an allocation? If not, what could and should replace it?

ASEAN's leaders have long sought reassurance that Beijing and Washington will not fight one another, collaterally damaging the region-the Thucydides trap sprung shut. Will this become an obsolete fear? Trump thinks of himself as a dealmaker. Xi Jinping may well want to make a deal. What if the elephants make love? Will that also flatten the grass? If Xi promised Chinese cooperation on other matters of importance to Trump, would Trump be willing in return to abet, by action or toleration, the eventual mutation of some or most if not all of 'ASEAN's region' into 'China's region'-part of an expanding Sinosphere of Chinese primacy and influence? The ' $G$ ' in 'G2' stands for 'Group', but it 
implies 'Global Governance'. At the global level one can imagine a variety of Sino-American trade-offs that could, positively or negatively, impact Southeast Asia.

\section{Failures and Transactions}

Beijing's and Washington's litmus-test failures differ. Beijing has failed its test in security terms by refusing to reassure Southeast Asia regarding the South China Sea-repudiating international law, militarizing land features, splitting ASEAN, and thwarting agreement on even a symbolic code of conduct, let alone a meaningful and enforceable one. But the stacks of renminbi are still on the table and mounting higher. They constitute a bet that Southeast Asians will want Chinese economic aid enough to accept, eventually, Chinese-style security as well. As it actuates the AIIB and launches the $21^{\text {st }}$ Century Maritime Silk Road in ways that would tie Southeast Asia closer to China economically, through connectivity, Beijing hopes in the long run to clientelise the region in security terms as well. Those hopes will rise if in implementing his campaign mantra-“America First”- Trump lowers the priority ranking of Southeast Asia on his administration's agenda.

Washington's failure is more comprehensive. In addition to possibly inheriting the vacuum in economic policy created by the apparent demise of the TPP, China has crossed with impunity all the main 'red lines' laid down by president Obama regarding security in the South China Sea. To no avail the US urged China not to upbuild or weaponise land features, to clarify the nine dashes, to agree to a code of conduct, and to implement the court's ruling. Beijing did not oblige. Washington did not even keep its own promise to conduct freedom of navigation operations at regular intervals in the SCS. China's economic initiatives served to cushion the effects of Chinese threats to security in the SCS. American reassurance was more broadly jeopardised by omens of pullback in both spheres-economy and security alike.

In October-November 2016, Philippine president Rodrigo Duterte and Malaysian Prime Minister Najib Razak travelled, separately, to Beijing. Their motivations were dissimilar. Given the circumstances noted above, however, one could be forgiven for recalling ancient voyages of ostensible fealty to the Middle Kingdom. In Beijing, neither visitor gave his host reason to believe that he disagreed with China's strictly bilateralist approach to managing the conflicting claims in the SCS. China's insistence on talking separately with each rival claimant maximises Beijing's clout at the negotiating table and shuts ASEAN out of the room.

Duterte and Najib were well rewarded. They returned with more promises of Chinese cash on the table, equivalent to an estimated $\$ 24$ billion in grants, loans, and deals for Manila and some $\$ 34$ billion for Kuala Lumpur (Reuters 2016). A 
few weeks later, on the security side, reports surfaced that Duterte would cancel two planned training exercises with the US (Parameswaran 2016b), one naval, one amphibious. Their maritime character was all the more likely to please Beijing. As for Najib, he had already agreed with $\mathrm{Xi}$ to jointly build with China, and then buy from China, four littoral patrol boats-the first significant defence deal between the two countries (MarEx 2016).

Alongside economy and security, these transactions implicated a third, moral sphere involving democracy, probity, human rights, and the rule of law. Duterte's approval if not instigation of the lawless killing of more than a thousand Filipinos alleged to be dealing in drugs; evidence of large-scale corruption implicating Najib and a state investment fund in Malaysia; Thailand's return to authoritarian rule ... all triggered rebuke from Washington while eliciting combinations of silence, sympathy, and support from Beijing. Eager to buy compliance, China helped finance Duterte's war on drugs, helped Najib by bailing out the Malaysian fund, and embraced the junta spawned by the Thai coup.

Perversely, in the US, Trump's strongman persona and chequered ethics may induce a narrowing of the moral gap between himself and certain authoritarian Asian leaders. To that extent, official American arguments for democracy in Southeast Asia may cease being advanced, or sound hypocritical if they are voiced. Inside ASEAN, already beleaguered liberal norms may lose further ground to default realism in domestic politics and foreign policy alike. In a worst-case scenario, China's illiberal influence could expand in all three spheres—economy, security, and governance as well.

\section{Horsing The Cow?}

In 2015, yet another realist in Singapore, Bilahari Kausikan, argued that ASEAN "is a cow, not a horse". "A cow will never become a horse", he said, "no matter how devoutly we may wish it". He acknowledged that ASEAN "is far from perfect", that "it certainly needs improvement", and that "there are many areas where its workings can be improved". But "we have to accept a cow as a cow" (Kausikan 2015).

For Kausikan, the job of ASEAN the cow is to keep doing what it has for so long so successfully done: fostering peace and comity in Southeast Asia. "In a sense", he said, "whatever ASEAN does in any field is primarily a means to this end: the creation and maintenance of order and civility through a process of working together". For him, that process is "at least as important as, and often more important than" the goal that ostensibly motivates the process. This "does not mean that goals are not important; it does not mean that we can just spin wheels forever without going anywhere. If we do so without caring about getting somewhere, disillusionment must eventually set in and ASEAN may well break up". But ASEAN may also break up "if we push the 
goal—whatever goal, however desirable—too hard". As Kausikan reasonably notes, "it is not always easy to maintain a balance or even know where the balance should lie" between aimlessness and insistence.

That is precisely the do-be-do-be balance that ASEAN so urgently needs to consider going forward. The problem, however, is not that critics of ASEAN-thecow mistake it for a horse. The problem is that ASEAN-the-cow is failing to achieve the one overriding goal that, in Kausikan's view, it is meant to pursue and achieve: "the creation and maintenance of order and civility through a process of working together".

China and the US have failed their Singaporean litmus tests. Has ASEAN met Kausikan's? It has not. ASEAN is not in wild disarray. But regarding the SCS, order and civility have not been maintained. The four ASEAN claimants have not been able to settle their overlapping claims. They have failed to "work together" to form a united front that might at least have slowed China's incremental absorption of ASEAN's maritime heart. Already, by Chinese law, non-Chinese fishermen must request and receive China's permission before fishing in the SCS. Someday access by Southeast Asians and others to the hydrocarbons beneath the sea could also be made conditional on evidence of fealty to China. Meanwhile China can continue, with impunity, exercising 'traditional fishing rights' in ASEAN's coastal EEZs in explicit violation of the arbitral court's ruling that no such rights exist under international law. The ASEAN states have not kept "order and civility" in the SCS by "working together." Disorder and incivility prevail inside ASEAN meeting rooms whenever the Cambodian delegation earns Chinese cash by derailing the 'ASEAN Way' (See also AFP 2016).

One could counter this critique by noting that at least Indonesia is not invading Singapore; the Philippines and Malaysia's are not physically fighting over a portion of Borneo that they have long contested; and Cambodia and Thailand are not locked in combat over disputed land along their common border. But are those the appropriate tests of ASEAN's success? After half a century spent cultivating each other's friendship in countless gatherings, agreements, and plans? Is it enough to say of ASEAN's performance that Southeast Asians are not actually dying in wars between its members? Or does that amount to damning with faint praise?

Because the cow metaphor lowers expectations, it undercuts the case for change. At its worst, default realism begets fatalism: nothing can be done, so why even try? It is the fatalism of resignation to an inevitably Sino-centric "community of destiny" that Beijing hopes will spread among its southern neighbours. China is betting that, among Southeast Asians, acquiescence in asymmetry dictated by geography will make creative policy ideas seem 'unrealistic', thereby discouraging local initiatives to soften the mainland's embrace. There is little evidence of collective ingenuity at the regional level in the ASEAN Institutes 
of Strategic and Security Studies (ASEAN ISIS), for example, whose array of think tanks might have been expected to generate fresh thinking.

Why not, in Kausikan's terms, try "horsing the cow"? ASEAN ISIS collectively, or a subset of the more active among its member institutes, could consider celebrating ASEAN's $50^{\text {th }}$ anniversary by requesting and compiling innovative policy proposals from across the region on a range of policy topics, from security to economy to society. Scholars, students, journalists, public intellectuals, all could contribute ideas. Proposers could recommend things for ASEAN as a whole to do, but they would be free to suggest initiatives by one, two, or more member countries that would not get bogged down in the ASEAN Way, and roles for non-Southeast Asian actors could be recommended as well. Especially promising ideas could be researched and discussed at a Track II conference in 2017 or 2018.

\section{Three Proposals}

Some creative proposals are already in circulation. Among them, three come readily to mind: 'ASEAN minus X'; an ASEAN Pacific Alliance; and a capstone East Asia Summit (EAS).

ASEAN minus $\mathrm{X}$ has already been used by ASEAN in economic arrangements. A subset of ASEAN members agrees to lower their tariffs on the understanding that other, economically less advanced members can sign on at a later date when they are likely to feel more able to reduce theirs too. Could that format - a willing subset of committed members with a door left open for the rest-apply to security arrangements as well?

Take the South China Sea. Myanmar borders the Bay of Bengal and the Andaman Sea; Cambodia and Thailand rim the Gulf of Thailand; Laos is landlocked. None of these four states is a claimant in the SCS. The four that do make claims-Brunei, Malaysia, the Philippines, and Vietnam-could consent to a code of conduct that they themselves would abide by. They could agree to respect one another's coastal EEZs in keeping with UNCLOS rules, including preventing illegal, unreported, and unregulated fishing (IUU). They could acknowledge the decision of the UNCLOS-consistent arbitral court in July 2016 and welcome its reminder to derive rights at sea from classifications of land features. Singapore and/or Indonesia might sign on as well, or even initiate the agreement, which could be open to adhesion by the two other claimants, China and Taiwan, and by users around the world including the US. The accord might even presage a "Treaty of Amity and Cooperation in Southeast Asia’s Maritime Domain” (Thayer 2015). Would China punish the signatory states in ASEAN by refusing their exports, ramming their boats, and threatening additional harm? Who knows? Such behaviour might browbeat some in Southeast Asia, but others would be remotivated to hedge against such an exercise of brute primacy by China in its 'near abroad'. 
In the economic realm, under a version of ASEAN minus $\mathrm{X}$, the four Southeast Asian participants in the stillborn TPP could explore ways of salvaging its more beneficial provisions by writing them into other prospective arrangements. Such plans could involve a coalition of other willing Asian members that in time might even someday link up with the US economy under an acronym less toxic than 'TPP' was to Trump.

Indonesia is advocating a different way of filling the vacuum in regional economic diplomacy that would likely follow the demise of the TPP — not an ASEAN minus $\mathrm{X}$, but a new 'ASEAN plus' that would cross the Pacific to encompass the members of the Pacific Alliance (PA) —Chile, Colombia, Mexico, and Peru. These Latin American states are distinguished by their west-facing coastlines, relative economic success, comparatively democratic politics, and more than 200 million total population. In 2012 they established the PA with a westward view toward economic engagement with Asia, but they have also been, on the whole, US-friendly as well. Indonesia's vice-president has already proposed attaching ASEAN to the PA in an ASEAN Pacific Alliance or APA (Halim 2016).

In geopolitical context, an APA would offer an alternative not only to the US-including-but-China-excluding TPP, but to the China-including-but-USexcluding RCEP as well. An APA would include no major power, unless that label fits Indonesia, a possibility that may help to explain Jakarta's support. The coinage could, however, evolve into a still broader agreement including the US and China, among other major economies.

A third proposal in circulation would build the EAS into ASEAN's capstone body (cf. Sukma 2016). This could involve both vertical and horizontal integration. Vertically, for example, the ASEAN Defense Ministers Meeting Plus $(\mathrm{ADMM}+)$ could be subsumed under, and therefore report to, the EAS, since the same eighteen states, including China and the US, belong to both bodies. Horizontally, the EAS's agenda could be widened to focus more on economic commitments and goals, including greater coordination across the many initiatives to build and repair infrastructure in Southeast Asia. An empowered EAS could improve complementarity across competing and centrifugal projects while reducing dependence on a single outside financier. American disowning of the TPP in particular argues for the involvement of the US and Japan in more viable ways and on terms that could limit Southeast Asian overreliance on Beijing's New Silk Road-building campaign and thereby alleviate the fiduciary and security concerns that the initiative has already raised (Kembara 2016; Tiezzi 2014).

\section{LOOKING FORWARD}

By ASEAN's $100^{\text {th }}$ birthday in 2067, if it lasts that long, what will it have become? In Sinatran terms, how will its "be" have been shaped, in its second half-century, 
by what it did or did not "do"? Does saying that a cow cannot be a horse excuse passive resignation? Is ASEAN thereby doomed to remaining what it already is, precluding creative ideas and possible change? Kausikan does not go that far; his cautious default realism is well taken. There is a lot that ASEAN cannot do in its present form, under its present leaders, and in presently China-challenged conditions. Yet no one could objectively scan ASEAN's first fifty years and conclude that the organization has remained the same-once a cow, always a cow. For better or worse, ASEAN's current form can and will evolve. Limits of longevity, actuarial if not political, will ensure that its leaders are replaced. Conditions inside and outside of Southeast Asia will not stay the same.

ASEAN in its present form bridges the divide between mainland and maritime Southeast Asia. Will the sub-continental north be absorbed, de facto if not de jure, into a 'greater China', while the insular south pursues a more open oceanic future? Will China entrench its primacy in the South China Sea and use it to coerce, clientelise, or otherwise subsume the maritime states as well? Will economic and political crises inside China turn it harmlessly inward? Or will they prompt Beijing to compensate by stoking ultra-nationalism at home while seeking dominance abroad? Will Beijing choose to pursue its 'China dream' in ways that do not keep its neighbours awake at night? Will China, Japan, India, and perhaps Indonesia collaborate in forming a new and stable regional order - a multipolar version of 'Asia for the Asians'? And how, in the next few years, will the 2016 election of an unqualified narcissist as president of the United States affect these and other possible scenarios?

Quite apart from indigenous change inside Southeast Asia, tensions and uncertainties are evident around the world. They show few signs of abating. Tumultuous circumstances may not allow ASEAN to remain a cow placidly chewing grass. Whatever ASEAN does become, its alternative futures should be considered now, carefully and creatively, while there is still time to prefer one scenario over the others and to follow up with steps that make it more likely. But taking steps is a "do," not a "be." Process for its own sake is a luxury that ASEAN cannot afford.

\section{References}

Acharya, Amitav. 2014. Constructing a Security Community in Southeast Asia: ASEAN and the Problem of Regional Order, 3rd edition. Abingdon, UK: Routledge.

AFP [Agence France-Presse]. 2016. Vietnam Warns South China Sea Is a "Test" of ASEAN, Business Standard, 25 July. Available at: http://www.business-standard.com/ article/pti-stories/vietnam-warns-south-china-sea-is-a-test-of-asean-116072500085_1. html (accessed on 14 December 2016).

Allison, Graham. 2015. The Thucydides Trap: Are the U.S. and China Headed for War? The Atlantic, 24 September. Available at: http://www.theatlantic.com/international/ archive/2015/09/united-states-china-war-thucydides-trap/406756/ (accessed on 24 November 2016). 
Allison, Graham. 2012. Avoiding Thucydides’s Trap, Financial Times, 22 August. Available at: http://belfercenter.ksg.harvard.edu/publication/22265/avoiding_thucydidess_trap.html (accessed on 24 November 2016).

Amaro, Yesenia. 2016. China MoU to Help “Reform” Judiciary, The Phnom Penh Post, 28 September. Available at: http://www.phnompenhpost.com/national/china-mou-helpreform-judiciary (accessed on 7 December 2016).

Bowring, Philip. 2016. Obituary: Association of Southeast Asian Nations (1967-2016), Asia Sentinel, 29 April. Available at: http://www.asiasentinel.com/politics/obituaryassociation-southeast-asian-nations/ (accessed on 13 November 2016).

Chan, Francis. 2016. China Criticised for Apparent Attempt to Divide ASEAN, The Straits Times, 26 April. Available at: http://www.straitstimes.com/asia/chinacriticised-for-apparent-attempt-to-divide-asean (accessed on 15 November 2016).

Chong, Ja Ian. 2016. ASEAN and the Risks of Business as Usual, Maritime Awareness Project, 3 August. Available at: http://maritimeawarenessproject.org/wp-content/ uploads/2016/08/analysis_chong_080316.pdf (accessed on 15 November 2016).

Chubb, Andrew. 2016. Did China Just Clarify the Nine-dash Line? East Asia Forum, 14 July. Available at: http://www.eastasiaforum.org/2016/07/14/did-china-just-clarifythe-nine-dash-line/ (accessed on 15 November 2016)

Eisenhower, John S. D. 1989. So Far from God: The U.S. War with Mexico, 1846-1848. New York: Random House.

Emmerson, Donald K. 2016. Sunnylands or Rancho Mirage? ASEAN and the South China Sea, YaleGlobal Online, 23 February. Available at: http://yaleglobal.yale.edu/ content/sunnylands-or-rancho-mirage-asean-and-south-china-sea (accessed on 16 December 2016).

Emmerson, Donald K. 2005. Security, community, and democracy in Southeast Asia: analyzing ASEAN. Japanese Journal of Political Science 6(2), 165-185.

Freedom House. 2016. Freedom in the World 2016. New York: Freedom House. Available at: https://freedomhouse.org/report/freedom-world/freedom-world-2016 (accessed on 29 November 2016).

Halim, Haeril. 2016. ASEAN-Pacific Axis Tabled as Alternative to TPP, The Jakarta Post, 21 November. Available at: http://www.thejakartapost.com/news/2016/11/21/aseanpacific-axis-tabled-as-alternative-to-tpp.html (accessed on 14 December 2016).

Heydarian, Richard Javad. 2016. The End of ASEAN? The World Post, 31 July. Available at: http://www.huffingtonpost.com/section/world (accessed on 15 November 2016).

Jones, David Martin and M. L. R. Smith. 2006. ASEAN and East Asian International Relations: Regional Delusion. Cheltenham, UK: Edward Elgar.

Jones, Lee. 2010. Still in the "driver's seat," but for how long? ASEAN's capacity for leadership in East-Asian international relations. Journal of Current Southeast Asian Affairs 29(3), 95-113.

Joshi, Vijay. 2016. ASEAN Split on How to Deal with China in South China Sea, The Jakarta Post, 24 July. Available at: http://www.thejakartapost.com/seasia/2016/07/ 24/asean-split-on-how-to-deal-with-china-in-south-china-sea-row-.html (accessed on 15 November 2016).

Kausikan, Bilahari. 2015. ASEAN Is a Cow, Not a Horse, The Middle Ground, 6 October. Available at: http://themiddleground.sg/2015/10/06/asean-cow-not-horse-bilaharikausikan/ (accessed on 2 December 2016).

Kembara, Giland. 2016. Promoting the $21^{\text {st }}$ Century Maritime Silk Road to ASEAN, The Diplomat, 10 October. Available at: http://www.thejakartapost.com/news/2016/10/ 10/promoting-21st-century-maritime-silk-road-asean.html (accessed on 13 December 2016). 
Kyaw, Hsu Mon. 2012. Myanmar Sends Team to Study ASEAN Summit Organisation, Myanmar Times, 19 November. Available at: http://www.mmtimes.com/index.php/ national-news/3167-govt-sends-team-to-study-asean-summit-organisation.html (accessed on 28 November 2016).

Kynge, James, Leila Haddou, and Michael Peel. 2016. How China Bought Its Way into Cambodia, The Financial Times, 8 September. Available at: https://www.ft.com/ content/23968248-43a0-11e6-b22f-79eb4891c97d (accessed on 7 December 2016).

Lee Hsien Loong. 2016. Speech by Prime Minister Lee Hsien Loong at Gala Dinner Hosted by US Chamber of Commerce and US-ASEAN Business Council. Prime Minister's Office, 2 August. Available at: http://www.pmo.gov.sg/mediacentre/ speech-prime-minister-lee-hsien-loong-gala-dinner-hosted-us-chamber-commerceand-us (accessed on 14 November 2016).

Lintner, Bertil. 2014. ASEAN Paralysis Gives China Free Hand in South China Sea, YaleGlobal Online, 12 August. Available at: http://yaleglobal.yale.edu/content/aseanparalysis-allows-china-free-hand-south-china-sea (accessed on 15 November 2016).

Majid, Munir. 2016. No Political Leadership in Failing ASEAN, The Star Online, 30 July. Available at: http:/www.thestar.com.my/opinion/columnists/comment/2016/07/30/ no-political-leadership-in-failing-asean/ (accessed on 15 November 2016).

Manning, Robert. 2016. Time to Rethink ASEAN, NIKKEI Asian Review, 6 September. Available at: http://asia.nikkei.com/Viewpoints/Viewpoints/Robert-A.-ManningTime-to-rethink-ASEAN (accessed on 15 November 2016).

MarEx. 2016. Malaysia Buys Chinese Patrol Boats, The Maritime Executive, 1 November. Available at: http://www.maritime-executive.com/article/malaysia-buys-chinesepatrol-boats (accessed on 1 December 2016).

Martel, Stéphanie. 2017. From ambiguity to contestation: discourse(s) of non-traditional security in the ASEAN Community. The Pacific Review 30. Available at: http://www. tandfonline.com/doi/full/10.1080/09512748.2016.1264462 (accessed on 16 December 2016).

Mauldin, William. 2016. Obama Administration Gives Up on Pacific Trade Deal, The Wall Street Journal, 11 November. Available at: http://www.wsj.com/articles/ obama-administration-gives-up-on-pacific-trade-deal-1478895824 (accessed on 15 November 2016).

Miller, Jonathan Berkshire, Daryl Morini, Jeffrey Ordaniel, and Meicen Sun. 2016. ASEAN Needs to Re-think Its Approach to Preventive Diplomacy, East Asia Forum, 13 April. Available at: http://www.eastasiaforum.org/2016/04/13/aseanneeds-to-re-think-its-approach-to-preventive-diplomacy/ (accessed on 15 November 2016).

Mogato, Manuel, Michael Lartine, and Ben Blanchard. 2016. ASEAN Deadlocked on South China Sea, Cambodia Blocks Statement, Reuters, 26 July. Available at: http://www.reuters.com/article/us-southchinasea-ruling-asean-idUSKCN1050F6 (accessed on 27 November 2016).

Parameswaran, Prashanth. 2016a. What Really Happened at the ASEAN-China Special Kunming Meeting, The Diplomat, 21 July. Available at: http://thediplomat. com/2016/06/what-really-happened-at-the-asean-china-special-kunming-meeting/ (accessed on 27 November 2016).

Parameswaran, Prashanth. 2016b. Where Are US-Philippine Defense Relations under Duterte? The Diplomat, 24 November. Available at: http:/thediplomat.com/2016/ 11/where-are-us-philippine-defense-relations-under-duterte/ (accessed on 1 December 2016). 
Paviour, Ben, and Kuch, Naren. 2016. After Sea Decision, Chinese Funds Flow In, Cambodia Daily, 16 July. Available at: https:/www.cambodiadaily.com/news/after-seadecision-chinese-funds-flow-in-115527/ (accessed on 27 November 2016).

Reuters. 2016. Malaysia’s Najib Risks Backlash at Home after Deals with China, Channel NewsAsia, 9 November. Available at: http://www.channelnewsasia.com/news/asia pacific/malaysia-s-najib-risks-backlash-at-home-after-deals-with-china/3268094.html (accessed on 1 December 2016).

Suropati, Untung, Yohanes Sulaiman, and Ian Montratama. 2016. Arungi Samudra Bersama Sang Naga: Sinergi Poros Maritim Dunia dan Jalur Sutra Maritim Abad $k e-21$ [Ocean Crossings with a Dragon: The Synergy between the Global Maritime Nexus and the 21st Century Maritime Silk Road]. Jakarta: Kompas Gramedia.

Storey, Ian J. 2016. ASEAN Initiatives Face Strong Headwinds, Maritime Awareness Project, 14 April. Available at: http://maritimeawarenessproject.org/2016/04/14/ asean-initiatives-face-strong-headwinds/ (accessed on 15 November 2016).

Sukma, Rizal. 2016. A Post-ASEAN Regional Order in East Asia? The Jakarta Post, 18 May. Available at: http://www.thejakartapost.com/news/2016/05/18/a-post-aseanregional-order-east-asia.html (accessed on 15 November 2016).

Tang, Siew Mun. 2016. Three Strategic Issues for ASEAN and China, ASEANFocus 10: 6-7, August-September. Available at: https://www.iseas.edu.sg/images/pdf/ASEAN FocusAugSep16.pdf (accessed on 24 November 2016).

Thayer, Carlyle A. 2015. Indirect Cost Imposition Strategies in the South China Sea: U.S. Leadership and ASEAN Centrality. Center for a New American Security. Available at: https:/www.files.ethz.ch/isn/190463/CNAS\%20Maritime\%208\%20Thayer.pdf (accessed on 13 December 2016).

The Guardian. 2016. Donald Trump Outlines Job Plan in YouTube Clip, 22 November. Available at: https:/www.theguardian.com/us-news/2016/nov/21/donald-trump-100days-plans-video-trans-pacific-partnership-withdraw (accessed on 27 November 2016).

Thucydides. 416 BCE. The Melian Dialogue. In The History of the Peloponnesian War. Ch. V, para. 84-116. Available at: http://www2.warwick.ac.uk/fac/arts/classics/ students/modules/introhist/usefuldocuments/thucydides_v.84-116.pdf (accessed on 14 November 2016).

Tiezzi, Shannon. 2014. The Maritime Silk Road vs. the String of Pearls, The Diplomat, 13 February. Available at: http://thediplomat.com/2014/02/the-maritime-silk-road-vsthe-string-of-pearls/ (accessed on 13 December 2016).

Wade, Geoffrey. 2011. Could ASEAN Drift Apart? YaleGlobal Online, 12 August. Available at: http://yaleglobal.yale.edu/content/asean-paralysis-allows-china-free-handsouth-china-sea (accessed on 15 November 2016).

Weissman, Jordan. 2016. Donald Trump Claims the TPP is a Nefarious Plot by China. Fact: China Is Not Part of the TPP, Moneybox, 10 November. Available at: http:// www.slate.com/blogs/moneybox/2015/11/10/donald_trump_says_tpp_is_a_nefarious_ plot_by_china.html (accessed on 27 November 2016).

Wanandi, Jusuf. 2016. Insight: Trust ASEAN to Solve the South China Sea Dispute, The Jakarta Post, 10 March. Available at: http://www.thejakartapost.com/news/2016/03/ 10/insight-trust-asean-solve-south-china-sea-dispute.html (accessed on 16 December 2016).

World Health Organization. 2016. Air Pollution Levels Rising in Many of the World's Poorest Cities, 12 May. Available at: http:/www.who.int/mediacentre/news/ releases/2016/air-pollution-rising/en/ (accessed on 28 November 2016). 